\title{
Saimiri sciureus' hard palate morphology ${ }^{1}$
}

\author{
Ana R. Lima ${ }^{2 *}$, Emerson T. Fioretto ${ }^{3}$, Aline A. Imbeloni ${ }^{4}$ and Érika Branco ${ }^{2}$
}

\begin{abstract}
Lima A.R., Fioretto E.T., Imbeloni A.A. \& Branco E. 2012. Saimiri sciureus' hard palate morphology. Pesquisa Veterinária Brasileira 32(5):459-462. Instituto de Saúde e Produção Animal, Universidade Federal Rural da Amazônia, Campus de Belém, PA 66077-530, Brazil. E-mail: ana.lima@ufra.edu.br

Primate order includes around 180 species. Morphological aspects of New World non-human primates (NHP) have been extensively investigated since last century. General commonsense describes oral cavity adaptations according to diet and feeding, dentition, tongue projection and head shape. Morphological appearance and dimension of the hard palate have been outstanding as interest in many species including man. Six young Saimiri sciureus hard palate were investigated. We measured the hard palate distance (HL), intercanine distance (ICD), intermolar distance (IMD), and interpremolar distance (IPD). Complete and incomplete palatine crests were quantified. We believe that better understanding of the mouth roof morphology will contribute to improve the management of captive animal's diet in order to re-introduce the animals in its habitat.
\end{abstract}

INDEX TERMS: Saimiri sciureus, non-human primates, oral cavity, wild animal, anatomy.

RESUMO.- [Morfologia do palato duro de Saimiri sciureus.] A ordem dos primatas inclui ao redor de 180 espécies, os aspectos morfológicos dos primatas não humanos do Novo Mundo tem sido investigados extensivamente desde o último século. 0 senso comum descreve adaptações na cavidade oral de acordo com a dieta e alimentação, dentição, projeção da língua e formato da cabeça. A aparência morfológica e a dimensão do palato duro demonstram interesses para muitas espécies incluindo o homem. Foram investigados seis palatos de Saimiri sciureus jovens os quais foram mensurados: o comprimento do palato duro (HL); a distância intercaninos (ICD); a distância intermolares (IMD) e, a distância interpremolar (IPD). As cristas palatinas completas e incompletas foram quantificadas. Nós acreditamos que para o melhor entendimento da morfologia da boca pode

\footnotetext{
${ }^{1}$ Received on July 17, 2011.

Accepted for publication on February 25, 2012

${ }^{2}$ Laboratório de Pesquisa Morfológica Animal (LaPMA), Faculdade de Medicina Veterinária, Universidade Federal Rural da Amazônia (UFRA), Av. Presidente Tancredo Neves 2501, Montese, Belém, PA 66077-530, Brazil. *Corresponding author: ana.lima@ufra.edu.br

${ }^{3}$ Laboratório de Biologia Celular e Estrutural, Departamento de Morfologia, Centro de Ciências Biológicas e da Saúde, Universidade Federal do Sergipe (UFS), Av. Marechal Rondon s/n, Rosa Elze, São Cristóvão, SE 49100- 000, Brazil

${ }^{4}$ Centro Nacional de Primatas (CENP), Instituto Evandro Chagas (IEC), Secretaria de Vigilância em Saúde (SVS), Ministério a Saúde (MS), BR 316 $\mathrm{Km}$ 7, Cx. Postal 44, Ananindeua, PA 67.030-000, Brazil.
}

contribuir para melhorar a dieta dos animais mantidos em cativeiro a fim de introduzir estes animais em seu habitat.

TERMOS DE INDEXAÇÃO: Saimiri sciureus, primatas não humanos, palato duro, animal selvagem, morfologia.

\section{INTRODUCTION}

Primate order includes around 180 species, traditionally divided into prosimians and simians, and usually inhabit in tropical or subtropical regions of America, Africa and Asia. Generally, simians demonstrate a wide range of characteristics varying in size and behavior. Primates are classified in non-human primates (NHP) from Old or New World Central and South Americas (Coimbra Filho 1982, Groves et al. 2005). New World NHP demonstrates distinguish habitats from those in Africa and Asia. In general Neotropical primates live essentially in trees, showing brachiation and climbing movements and, rarely terrestrial quadrupedalism (Rylands et al. 2000, Groves et al. 2005).

Morphological aspects of New World NHP have been extensively investigated since last century (Castelli \& Huelke 1964, Zingeser 1976, Feagle 1999, Ferreira et al. 2000, Blumenchein \& Ferreira 2002, Ferreira et al. 2005, Branco et al. 2010, Lima et al. 2011), including some descriptions of digestive system in the head (Geist 1961, Molinari et al. 1994a,b). General commonsense describes oral cavity adaptations according to diet and feeding, dentition, tongue projection and head shape (Hildebrand 1995). 
Palate is the mouth roof in humans and other mammals that separates the oral and nasal cavities. It is divided into two portions, one anterior and one posterior, according to the structure. The anterior portion is the hard palate, which is ossified and present a thin horizontal bone composed by two palatal processes of maxilla and two horizontal plates of palatine bones, linked by a crucial suture among the described bones. Soft palate, posterior portion, is basically muscular. Palate is covered by stratified squamous epithelia in the oral portion.

Morphological appearance and dimension of the hard palate have been of interest in many species including man (Moreira et al. 2006). Hard palate is also formed by a region called palatine rugae, which comprehends the palatine crests. Palatine crests are transversal projections of the hard palate, its number, orientation and height are specific for each specie (Eisentraut 1976), and for example, rats demonstrate at least nine rows of palatine crests (Peterkova et al. 1987, Charles et al. 2007). In addition to the teeth and tongue, the palatine crests participates in mastication, its function is related to sensation of taste, and, auxiliary to apprehension and crushing food (Peterkova et al. 1987).

Investigations of organs morphology and systems physiology contributes to the wild animal veterinary medicine and conservation of species. Besides some descriptions of palate in primates (Sicher \& Dubrul 1997, Moore \& Dalley 2001); further detail of palatine crests morphology is still absent. We believe that the better understanding of mouth roof morphology would contribute to improve the management of captive animals diet in order to re-introduce the animals in its habitat. Based on this, in this study we aimed to describe Saimiri sciureus hard palate and palatine crests, in order to contribute to the understanding of the morphology of the roof of mouth in this specie.

\section{MATERIALS AND METHODS}

Six young Saimiri sciureus, three male and three female, that died from natural causes, were obtained at Centro Nacional de Primatas (Cenp), PA, Brazil. Specimens were fixed in a $10 \%$ formaldehyde solution. Based on the literature (Canellas et al. 1995), and using a digital calipers (unit: $\mathrm{cm}$ ), the hard palate was measured as follows: hard palate length (HL) from incisive papillae to hard palate caudal margin, intercanine distance (ICD), intermolar distance (IMD), and, interpremolar distance (IPD). Complete and incomplete palatine crests were quantified. Palatine crest that extend from lateral border of hard palate to the palatine rafe in both sides was considered a complete palatine crest; any interruption on its extension were classified as incomplete palatine crest. Structure identifications obeyed the Nomina Anatomica Veterinaria (1994) and literature illustrations (Schaller 1999).

\section{RESULTS}

Saimiri sciureus hard palate demonstrated incisive papilla, palatine rafe and transversal crests. Hard palate bone layer was composed by horizontal plates of maxilla and palatine bones; submucosa was adhered to the periosteum. Palatine rafe, a shallow median sulcus, extended caudally from the incisive papilla, between the first pair of palatine crests, to the aboral margin of the hard palate. Palatine crests formation initiated caudally to the incisive papillae in line to the canine teeth. Palatine crests were of two types: complete or incomplete, both being concave and very prominent. Crests were covered by an unpigmented mucosa. Palatine crests extended from the palatine rafe in direction to the lateral gingival margin. Complete palatine crests were transversally aligned and oriented rostral-caudally. First pair of palatine crests extended from palatine rafe to the diastema between last incisive and canine teeth. Palatine crests distribution, drawn lines of measured axes are represented in Figures 1 and 2. Measurements are represented in Table 1.

\section{DISCUSSION}

General features of Saimiri sciureus' hard palate is considered some similar to the descriptions for other mammals.
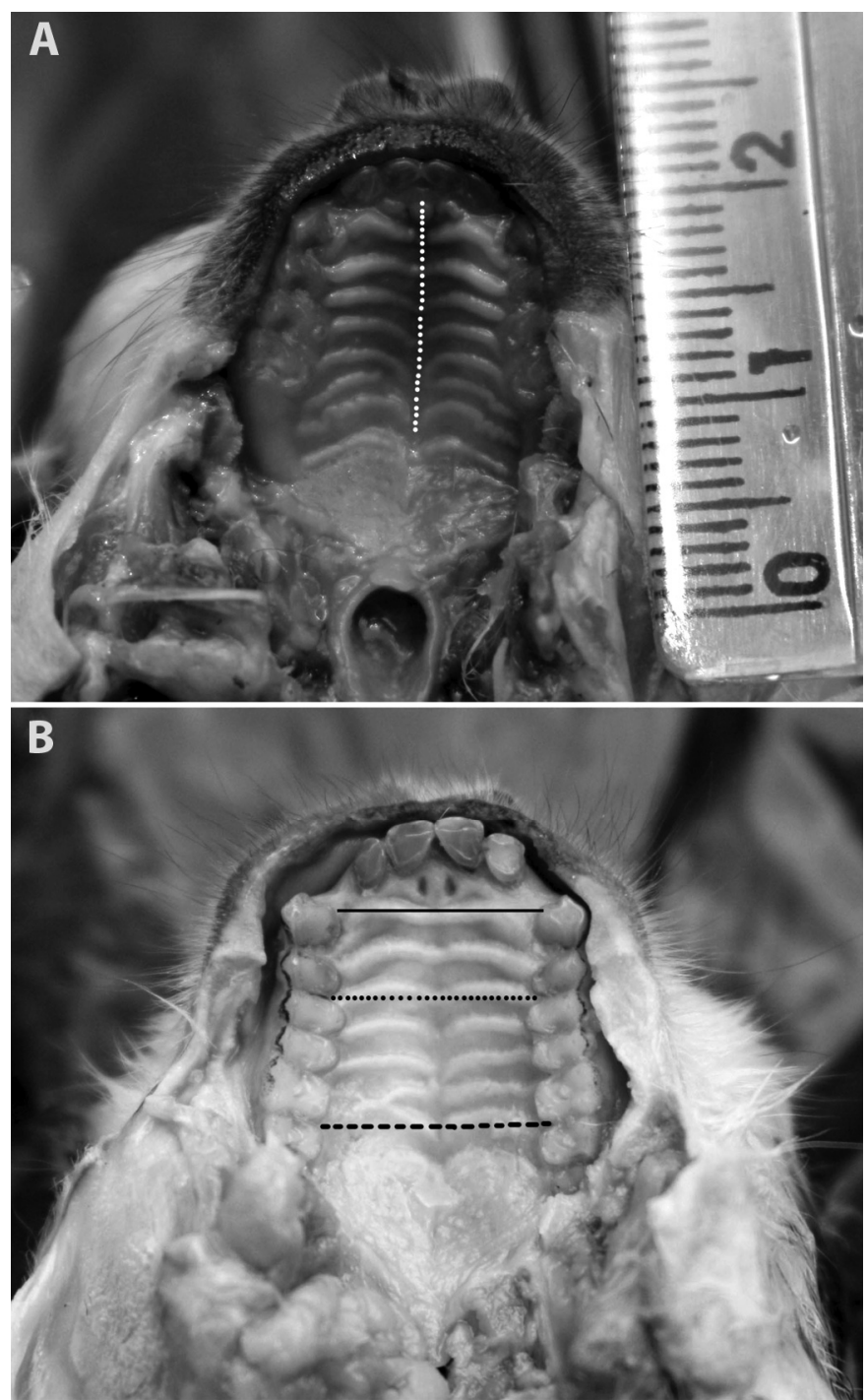

Fig.1. Hard palate of Saimiri sciureus. (A) Female specimen, hard palate length (HL) drawn line. (B) Male specimen; intercanine (ICD) distance (continuos line); interpremolar (IPD) distance (dotted line) and intermolar (IMD) distance (discontinued line). 


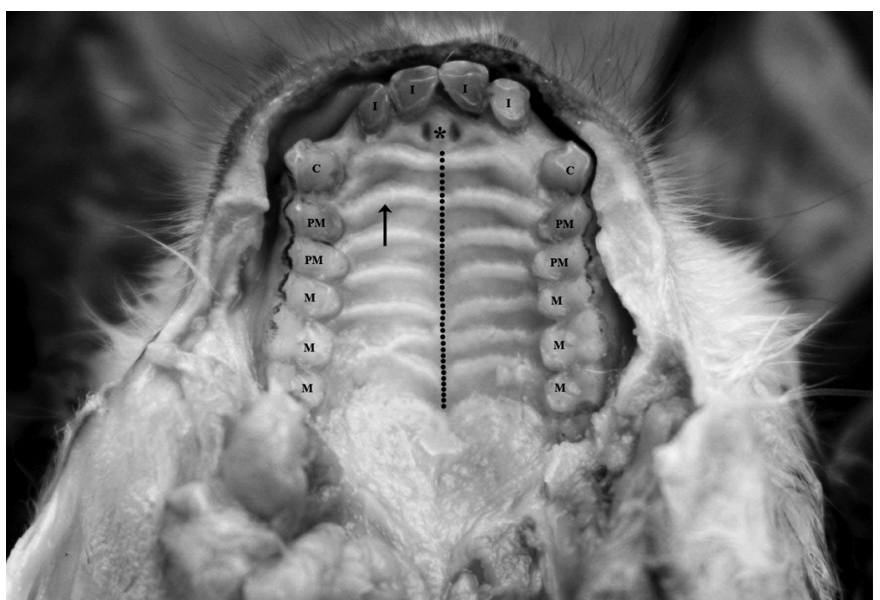

Fig.2. Hard palate of Saimiri sciureus demonstrating incisive (I); canine (C); premolar (PM) and molar (M) teeth; incisive papilla $\left(^{*}\right)$; palatine crests (arrows) and palatine rafe (discontinued line).

Table 1. Hard palate distance measurements and number of palatine crests of Saimiri sciureus

\begin{tabular}{lcccccc}
\hline & HL & ICD & IPD & IMD & \multicolumn{2}{c}{ Number of palatine crests } \\
\cline { 6 - 7 } & $(\mathrm{cm})$ & $(\mathrm{cm})$ & $(\mathrm{cm})$ & $(\mathrm{cm})$ & Complete & Incomplete \\
\hline Female average & 1.5 & 0.85 & 0.85 & 1.05 & 7 & 1 \\
SD & 0.28 & 0.21 & 0.07 & 0.07 & 0 & 0 \\
Male average & 1.65 & 1.0 & 0.95 & 1.15 & 7 & 1 \\
SD & 0.07 & 0.14 & 0.07 & 0.07 & 0 & 0
\end{tabular}

$\mathrm{HL}=$ hard palate distance, $\mathrm{ICD}=$ intercanine distance, $\mathrm{IPD}=$ interpremolar distance, $\mathrm{IMD}=$ intermolar distance, $\mathrm{SD}=$ standard deviation.

Similarities are associated to the presence of incisive papilla, palatine rafe and transversal crests, therefore, maxilla and palatine bones also forms the hard palate (Llorca 1952, Warwick \& Williams 1979).

Cebus apella is also a NHP of New World, which morphology has been investigated; Saimiri sciureus can be considered similar to Cebus apella due to its size, behavior and diet. Comparison between these species revealed that palatine rafe origin, extension and localization as well as palatine crests formation and orientation behavior similarly in both species (Mortoza et al. 2008).

Origin, extension and disposition of first pair of palatine crest were considered similar to the descriptions for other species (Barone 1956, Canellas et al. 1995). Complete palatine crests in Saimiri sciureus are similar to Cebus apella and to the observations in other mammals. Rostral-caudal orientation of palatine crests, also observed in Saimiri sciureus, was associated to facilitate food transit in direction to the pharyx as demonstrated in other mammals (Barone 1956, Schultz 1960, Warwich \& Willians 1979, Halata et al. 1999, Mortoza et al. 2008).

\section{CONCLUSION}

Based on the results we can conclude that the morphology of hard palate and palatine crests of Saimiri sciureus are some similar to the Cebus apella (Mortoza et al. 2008).

Acknowledgements.- The authors would like to express their most sincere thanks to CENP (Centro Nacional de Primatas), Ananindeua, PA, for his assistance to supply the material for this study, and to Universidade Federal Rural da Amazonia for financial support.

\section{REFERENCES}

Barone R. 1956. Anatomia comparata dei mammiferi domestici. V. Terzo Milano. Edagricole, Itália. 537p.

Branco E., Lacreta Jr A.C.C., Ishizaki M.N., Pereira W.L.A., Meneses A.M.C., Muniz J.A.P.C. \& Fioretto E.T. 2010. Morfologia macroscópica e morfometria do aparelho urogenital do macaco de cheiro (Saimiri sciureus Linnaeus, 1758). Biotemas 23:197-202.

Blumenchein A.R. \& Ferreira J.R. 2002. Anatomic study of the neotropic primates' submandibular gland ducts (Cebus apella Linnaeus, 1766). Revta Chil. Anatomia 20:55-61.

Canellas L.F.L., Souza W.M., Miglino M.A. \& Perri S.H.V. 1995. Características anatômicas das pregas palatinas transversais em bovinos da raça nelore. Revta Unimar 17:281-290.

Castelli W.A. \& Huelke D.F. 1964. The arterial system of the head and neck of the Rhesus monkey with emphasis on the external carotid system. Am. J. Anatomy 116:149-170.

Charles C., Pantalacci S., Peterkova R., Peterka M., Laudet V. \& Viriot L. 2007. Disruption of the palatal rugae pattern in Tabby mutant mice. Eur. J. Oral Sci. 115:441-448.

Coimbra Filho A.F. 1982. Distribuição geográfica, ecologia, extinção e preservação de platirrinos, p.83-103. In: Saldanha P.H. (Ed.), Genética Comparada de Primatas Brasileiros. Sociedade Brasileira de Genética, São Paulo.

Eisentraut M. 1976. Das Gaumenfaltenmuster der Säugetiere und seine Bedeutung für Stammesgeschichtliche und taxonomische Untersuchungen. Tyska, Bonner Zoologische Monographien. 214p.

Feagle J.G. 1999. The primate body, p.14-17. In: Feagle J.G. (Ed.), Primate Adaptation and Evolution. $2^{\text {nd }}$ ed. Academic Press, San Diego.

Ferreira J.R., Blumenchein A.R. \& Oliveira A.B.S. 2000. Estudo anatômico do modelo arterial de vasos responsáveis pelo aporte sanguíneo da glândula submandibular de primatas neotropicais (Cebus apella Linnaeus, 1766). Acta Scientiarum 22:573-579.

Ferreira J.R., Pinto Júnior N., Kajita D., Cirqueira D.S. \& Nogueira D.J. 2005. Estudo da anatomia descritiva e topográfica do músculo digástrico em primatas (Cebus apella Linnaeus, 1766). Braz. J. Vet. Res. Anim. Sci. 42: 113-121.

Geist F.D. 1961. Nasal cavity, larynx, mouth and pharynx, p.329-330. In: Linebak P. (Ed.), The Anatomy of the Rhesus Monkey (Macaca mulatta). Hafner, New York.

Groves C., Wilson D.E. \& Reeder D.M. 2005. Mammal Species of the World. $3^{\text {rd }}$ ed. Johns Hopkins University Press, Baltimore, p.1-184.

Halata Z., Cooper B.Y., Baumann K.I., Schwegmann C. \& Friedman R.M. 1999. Sensory nerve endings in the hard palate and papilla incisive of the goat. Exp. Brain Res. 129:218-28.

Hildebrand M. 1995. Análise da Estrutura dos Vertebrados. Atheneu, São Paulo. 700p.

International Committee on Veterinary Gross Anatomical Nomenclature 1994. Nômina Anatômica Veterinaria. $4^{\text {th }}$ ed. Zürich. 614p.

Lima A.R., Fioretto E.T., Fontes R.F., Imbeloni A.A., Muniz J.A.P.C. \& Branco E. 2011. Caring about medullary anesthesia in Saimiri sciureus: the conus medullaris topography. Ann. Acad. Bras. Sci. 83:1339-1343.

Llorca F.0. 1952. Intestino cefálico, p.351-353. In: Llorca F.O. (Ed.), Anatomia Humana. Tomo Tercero. Editorial Científico Médica, Barcelona.

Molinari S.L., Miranda Neto M.H. \& Madeira M.C. 1994a. Número e localização dos forames mentais do macaco de cheiro (Saimiri sciureus Linnaeus, 1758). Revta Unimar 16:427-435.

Molinari S.L., Navarro J.A.C., Toledo Filho J.C., Costa P.F. \& Miranda Neto M.H. 1994b. Systematization of the branching of the inferior alveolar nerve in the squirrel monkey mandible (Saimiri sciureus). Revta Bras. Ciênc. Morfológicas 11:57-60.

Moore K.L. \& Dalley A.F. 2001. Cabeça, p.836-837. In: Moore K.L. \& Dalley 
A.F. (Eds), Anatomia Orientada para a Clínica. $4^{\underline{a}}$ ed. Guanabara Koogan, Rio de Janeiro.

Moreira R.S., Sgrott E.A., Seiji F. \& Smith R.L. 2006. Biometry of hard palate on digital Photographs: A methodology for quantitative measurements. Int. J. Morphology 24:19-53.

Mortoza A.R., Ferreira V.S., Siqueira P.A., Ramos A.L.M. \& Ferreira J.R. 2008. Aspectos anatômicos do palato duro do primata Cebus apella (Linnaeus, 1766). Biotemas 21:107-113.

Peterkova R., Klepacek I. \& Peterka M. 1987. Prenatal development of rugae palatinae in mice: scanning electron microscopic and histologic studies. J. Craniofac. Genet. Dev. Biol. 7:169-89.

Rylands A.B., Schneider H., Langguth A., Mittermeier R.A., Groves C.P. \&
Rodriguez-Luna E. 2000. An assessment of the diversity of New World primates. Neotropical Primates 8:61-93.

Schultz A.H.D. 1960. Palatine ridges, p.127-138. In: Hofer H., Schultz A.H. \& Starck D. (Eds), Primatologia Handbuch der Primatenkunde. Band III, Teil 2. S. Karger, Basel.

Sicher H. \& Dubrul L.L. 1997. Anatomia Bucal. 6ª ed. Guanabara Koogan, Rio de Janeiro. 296p.

Warwick R. \& Willians P.L. 1979. Esplancnologia, p.1137-1140. In: Warwick R. \& Willians P.L. (Eds), Gray Anatomia. Tomo II. 35ํㅡ ed. Guanabara Koogan, Rio de Janeiro.

Zingeser M.R. 1976. Arch form, tooth size, and occlusomandibular kinesis in the Ceboidea. Am. J. Physical Anthropologists 45:317-330. 